\title{
Estimation of Digestibility from In Vitro Rumen Fermentation Data in Some Forages of Puerto Rico
}

\author{
José A. Arroyo-Aguilú ${ }^{1}$
}

\section{INTRODUCTION}

The present study was undertaken as an attempt to estimate in vivo forage energy digestibility from in vitro cellulose digestion (I.V.C.D.) in some forages of Puerto Rico. High correlations between measures of in vivo and in vitro digestion of forage crops have been found by Hershberger et al. $(10)^{2}$, Donefer et al. (8), Baumgardt et al. (5), Naga and El-Shazly (12), Reid et al. (14), Arroyo-Aguilú et al. (1), and Chalupa and Lee, Jr. (6). As a result, I.V.C.D. is being widely used as a biological approach to forage nutritive evaluation. This technique is accurate, simple, less costly, and less time-consuming than in vivo evaluations.

\section{MATERIALS AND METHODS}

Forage samples of known nutritive value (4), as determined in conventional digestion trials with dairy cattle (3), were used in this study to evaluate the in vitro procedure. The forages used were Merker grass (Pennisetum purpureum), Guinea grass hybrid (Panicum maximum), and Buffel grass (Cenchrus ciliaris) harvested at 49 to 55 and at 63 to 69 days of age at the Gurabo Substation farm. The grasses were fertilized at the rate of 400 pounds of $\mathrm{N}, 300$ of $\mathrm{P}_{2} \mathrm{O}_{5}$, and 300 of $\mathrm{K}_{2} \mathrm{O}$ per acre per year. Forty-two samples, seven from each grass, and six composite samples of these same grasses were included in each run.

One-gram samples of ground dry forage were weighed into 100-ml. lipless beakers to serve as artificial rumina (1). Twenty milliliters of the filtered rumen-fluid inoculum and $30 \mathrm{ml}$. of a phosphate nutrient solution (1), were added to each beaker and mixed gently with the hay substrate.

Carbon dioxide was passed over the surface of the beaker contents. Immediately the beakers were closed with stoppers, equipped with Bunsen-type gas-release valves, and fermented in an incubator at $39^{\circ} \mathrm{C}$.

Two beakers, one with a 0.5 -gm. sample of crystalline cellulose $\mathrm{s}^{3}$ and the other with a $40-\mathrm{ml}$. rumen-fluid sample, were always included in each run.

${ }^{1}$ Assistant Nutritionist, Animal Husbandry Department, Agricultural Experiment Station, University of Puerto Rico, Río Piedras, P.R. The author wishes to express his gratitude to Dr. Luis Rivera-Brenes, Head of the Animal Husbandry Department of this Station, for his cooperation during the initiation of this study, and to the Plant Breeding Department of this Station for supplying the vegetative material used in this study.

${ }^{2}$ Italic numbers in parentheses refer to Literature Cited, p. 139.

${ }^{3}$ Avicel used is a product of American Viscose Corp., Marcus Hook, Pa. Trade name is used to provide factual information. This does not imply guarantee, warranty, or endorsement. 
The artificial-rumen samples were incubated for 12-, 24-, 36-, and 48-hour periods on 3 days to account for day-to-day variation. Fermentation periods of 60 and 72 hours were also conducted on duplicate forage samples using rumen-fluid inoculum from two fistulated animals (2).

At the end of the fermentation periods, $1 \mathrm{ml}$. of $2 \mathrm{~N} \mathrm{H}_{2} \mathrm{SO}_{4}$ was added to each beaker to stop microbial activity. The samples were then dried in an oven at $65^{\circ} \mathrm{C}$.

Cellulose was determined by the Matrone modification (11) of the Crampton and Maynard procedure (7). I.V.C.D. coefficients (table 1) were calculated according to Arroyo-Aguilú et al. (1).

Two rumen-fistulated cows fitted with permanent rumen-cannulas

TABLE 1.-Average percentage in vitro cellulose digestion data for 3 forage grasses of known nutritive value

\begin{tabular}{|c|c|c|c|c|c|c|c|}
\hline \multirow{2}{*}{ Forage grass } & \multirow{2}{*}{ Age } & \multicolumn{6}{|c|}{ Data on in vitro cellulose digestion, in hours- } \\
\hline & & 12 & 24 & 36 & 48 & 60 & 72 \\
\hline & Days & Percent & Percent & Percent & Percent & Percent & Percent \\
\hline Merker & $49-55$ & 17.25 & 31.79 & 42.90 & 47.86 & 46.77 & 45.44 \\
\hline Buffel & do. & 11.63 & 27.33 & 36.82 & 42.71 & 46.97 & 46.07 \\
\hline Guinea & do. & 15.57 & 32.31 & 42.20 & 45.47 & 49.84 & 48.65 \\
\hline Merker & $63-9$ & 13.22 & 25.76 & 35.41 & 43.14 & 45.27 & 46.56 \\
\hline Buffel & do. & 6.32 & 24.07 & 30.77 & 32.66 & 40.00 & 39.32 \\
\hline Guinea & do. & 13.27 & 26.83 & 34.00 & 40.05 & 40.37 & 43.78 \\
\hline
\end{tabular}

served as the sources of rumen-fluid inoculum. Both animals were fed daily grass hay ad libitum.

Correlation and regression analyses were made according to the method of Steel and Torrie (15).

\section{RESULTS AND DISCUSSION}

The rates of percentage I.V.C.D. for 12-, 24-, 36-, and 48-hour fermentation periods (table 1) were correlated with percentages of digestible dry matter (D.D.M.), total digestible nutrients (T.D.N.), digestible energy (D.E.), and nutritive value index (N.V.I.) as shown in table 2. Percentage relative intake (R.I.) and percentage voluntary intake (V.I.) were correlated with 12- and 24-hour I.V.C.D. rates, respectively. I.V.C.D. rates were pooled and are presented in figure 1.

These grasses were evaluated in vitro up to 72-hour fermentation periods (fig. 1). However, correlation analyses and regression equations (15) were computed between in vivo data and in vitro values obtained in fermentation 
periods of $12,24,36$, and 48 hours only. Mold growth was evident at 60 hours on the substrate surface.

Low correlations $(r)$ between 12-hour I.V.C.D. values and D.D.M. $(r=0.76)$, T.D.N. $(r=0.64)$, N.V.I. $(r=0.64)$, and D.E. $(r=0.60)$ were obtained. In New Jersey, Arroyo-Aguilú et al. (1) found also a nonsignificant correlation $(r=0.41)$ between 12 -hour I.V.C.D. and N.V.I. This might

TABLE 2.-Regression equations and correlation coefficients for estimating forage nutritive value from in vitro forage cellulose digestion

\begin{tabular}{l|c|c}
\hline \multicolumn{1}{c|}{ Variable correiated $^{1}$} & Regression equations & Correlation coefficients ${ }^{2}(r)$ \\
\cline { 2 - 3 } D.D.M. (Y) with- & & \\
12-hour I.V.C.D. & $Y=42.41+1.239 X$ & 0.76 \\
24-hour I.V.C.D. & $Y=12.39+1.641 X$ & $.89^{*}$ \\
36-hour I.V.C.D. & $Y=12.84+1.230 X$ & $.95^{* *}$ \\
48-hour I.V.C.D. & $Y=16.01+1.009 X$ & $.87^{*}$ \\
T.D.N. (Y) with- & & \\
12-hour I.V.C.D. & $Y=40.14+.869 X$ & .64 \\
24-hour I.V.C.D. & $Y=14.88+1.301 X$ & $.84^{*}$ \\
36-hour I.V.C.D. & $Y=17.79+.906 X$ & $.94^{* *}$ \\
48-hour I.V.C.D. & $Y=20.39+.737 X$ & .76 \\
D.E. (Y) with- & $Y=74.90+1.552 X$ & .60 \\
12-hour I.V.C.D. & $Y=2.461 X-14.05$ & $.83^{*}$ \\
24-hour I.V.C.D. & $Y=1.801 X-11.76$ & $.94^{* *}$ \\
36-hour I.V.C.D. & $Y=1.370 X-2.60$ & .73 \\
48-hour I.V.C.D. & $Y=43.84+.521 X$ & \\
N.V.I. (Y) with- & $Y=22.53+.998 X$ & .64 \\
12-hour I.V.C.D. & $Y=22.34+.762 X$ & .74 \\
24-hour I.V.C.D. & $Y=20.49+.716 X$ & $.81^{*}$ \\
36-hour I.V.C.D. & $Y$. & $.85^{*}$ \\
48-hour I.V.C.D. & $Y$ & \\
\hline
\end{tabular}

${ }^{1}$ See text pp. 133-4 for explanation of abbreviations.

${ }^{2}$ Significant at the 5 -percent level of probability $(P<0.05)$; ** Significant at the 1-percent level of probability $(P<0.01)$.

have been because within-trial variability is greatest at this fermentation period. Donefer et al. (8) and Chalupa and Lee, Jr. (6) reported significant correlations between 12-hour I.V.C.D. and N.V.I.

No relationship between ad libitum intake (R.I. and V.I.) with 12- and 24-hour I.V.C.D. rates was obtained. The lag periods at early stages of incubation, the shock in transfer of the micro-organisms from the animal to the in vitro system, and the poor initial availability of the nutrients could possibly slow down the rate of I.V.C.D. At 12-hour periods, results were rather inconsistent and variable, and probably affected the 24-hour period somewhat. Reid et al.(14) observed no relationship between V.I. 
and I.V.C.D. Nevertheless, Chalupa and Lee, Jr. (6) obtained high correlations between R.I. and 12- and 18-hour I.V.C.D. Further work and more data are probably needed to clarify this phase of the in vitro work.

Significant correlations between 24-hour I.V.C.D. and D.D.M. $(r=$

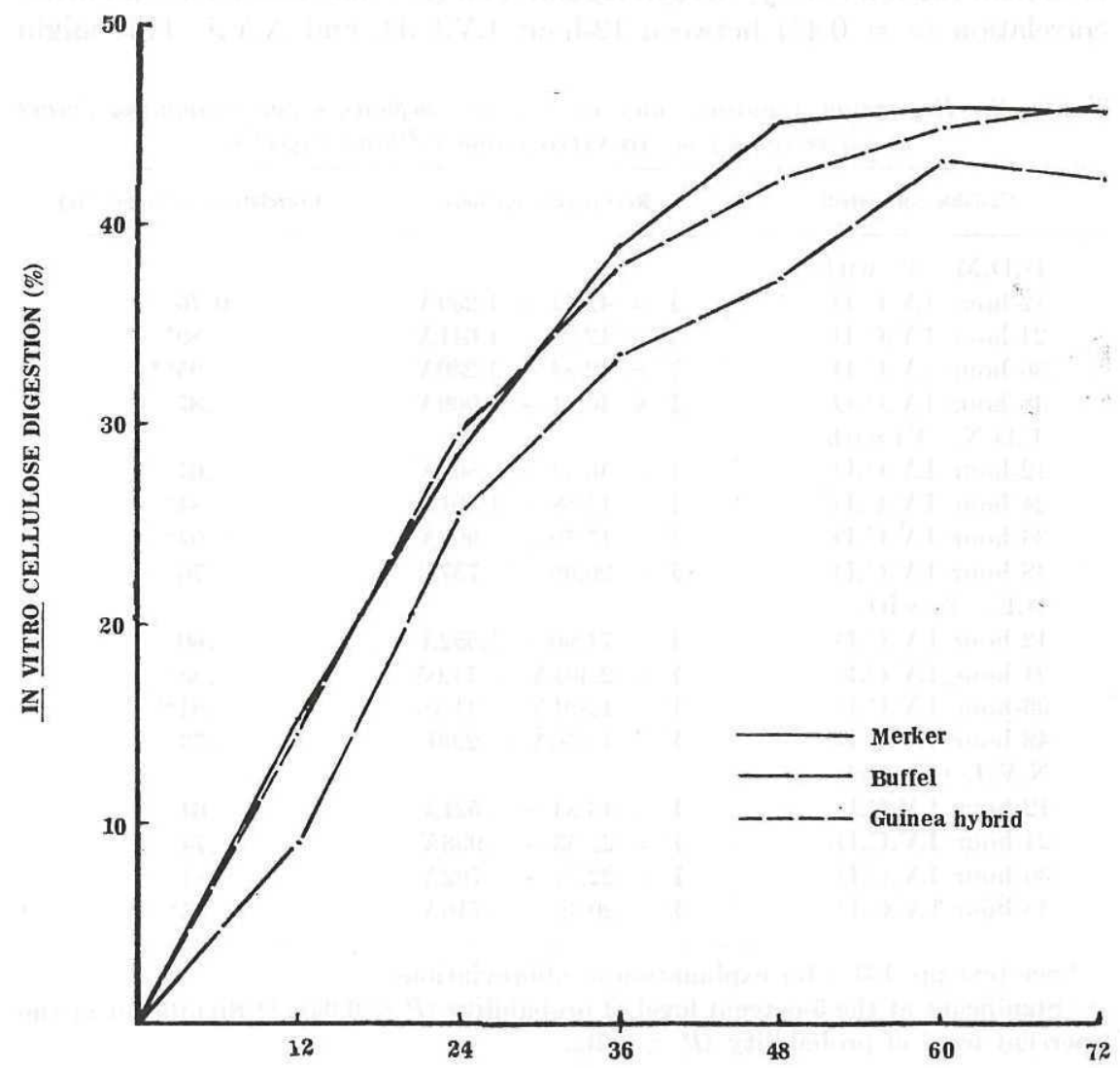

FERMENTATION TIME (HOURS)

Fig. 1.-Rate of in vitro cellulose digestion of Merker, Guinea hybrid, and Buffel grasses.

0.89), T.D.N. $(r=0.84)$ and D.E. $(r=0.83)$ were obtained. I.V.C.D at 24 hours was nonsignificantly correlated with N.V.I. $(r=0.74)$. D.E. correlations with 24 -hour I.V.C.D. were reported as highly significant by Hershberger et al. (10), Naga and El-Shazly (12), Baumgardt et al. (5), Donefer et al. (8), and Arroyo-Aguilú et al. (1). Chalupa and Lee, Jr., (6) significantly correlated 24-hour I.V.C.D. with both D.E. and T.D.N. 
Arroyo-Aguilú et al. (1) obtained, with 24-hour I.V.C.D., highly significant correlations for T.D.N. but significant correlations for N.V.I. Lag-time differences were still observed at incubation periods of 24 hours, although good correlations were obtained.

Thirty-six-hour I.V.C.D. values were highly significantly correlated with D.D.M. $(r=0.95)$, D.E. $(r=0.94)$ and T.D.N. $(r=0.94)$. N.V.I. $(r=$ 0.81 ) was significantly correlated with I.V.C.D. at 36 hours. These correlations suggest that 36 -hour incubation periods may offer the best estimates of energy availability. Fermentation periods of approximately 36 hours seem to be a measure of total digestion. Highly significant correlations between I.V.C.D. at 36 hours and D.D.M. or D.E. were obtained by Reid et al. (14).

Correlations between D.D.M. $(r=0.87)$ and N.V.I. $(r=0.85)$ with 48-hour I.V.C.D. were found to be significant. I.V.C.D. at 48 hours was found to be nonsignificant with both T.D.N. $(r=0.76)$ and D.E. $(r=0.73)$. Reid et al. (14) found I.V.C.D. between 24 and 48 hours to be highly correlated with D.D.M.

Maximum cellulose digestion was apparently obtained at 60 hours (fig. 1) for four of the six forages studied. The remaining two grasses, Merker and Guinea at 63 to 69 days of age, increased their I.V.C.D. values at 72 hours by 1.29 and 3.41 percentage units, respectively. This is in agreement with the results of Quicke et al. (13), in which maximum cellulose digestion of more mature forages was obtained with a longer fermentation period.

No marked differences in 60- and 72-hour I.V.C.D. values were observed when rumen-fluid inoculum from two different sources was used. Donefer et al. (9) obtained similar results in cellulolytic response when inoculum donor steers were fed the same forage.

\section{SUMMARY AND CONCLUSIONS}

Forty-two samples (seven from each grass) and six composite samples of Merker grass (Pennisetum purpureum), Guinea grass hybrid (Panicum maximum), and Buffel grass (Cenchrus ciliaris) were used in this study to evaluate the artificial rumen, or in vitro cellulose digestion, technique (1). These forage samples of known nutritive value (4), as determined in conventional digestion trials with cattle (3), were harvested at 49 to 55 and at 63 to 69 days of age at the Gurabo Substation farm.

No relationship was found between ad libitum intake (R.I. or V.I.) and 12- and 24-hour I.V.C.D. Within-trial variability due to lag-time differences could probably account for this.

I.V.C.D. at 36 hours may be used as the best estimate of forage digestibility in terms of D.D.M. $(r=0.95)$, D.E. $(r=0.94)$, and T.D.N. $(r=$ 0.94). Forty-eight-hour I.V.C.D. values could also be used as a predictor 
of forage digestibility in terms of D.D.M. $(r=0.87)$ and N.V.I. $(r=0.85)$. Nevertheless, the highest correlations were obtained with in vitro values at 36 hours. There was a tendency for correlation coefficients to increase up to 36-hour digestion periods with increasing fermentation rates. From the data in the present study, the regression equations to predict in vitro D.D.M. $(Y)$, in vitro D.E. $(Y)$, and in vitro T.D.N. $(Y)$ from 36-hour I.V.C.D. $(X)$ were $Y=12.84+1.23 X, Y=1.801 X-11.76$, and $Y=$ $17.79+0.906 X$, respectively.

Maximum cellulose digestion was apparently obtained at 60 hours for four of the six forages studied. When two inoculum donor animals were fed the same forage, no marked differences in 60- and 72-hour I.V.C.D. values were observed.

\section{RESUMEN Y CONCLUSIONES}

Cuarenta y dos muestras (siete de cada yerba) y seis muestras compuestas de yerba Merker (Pennisetum purpureum), híbrido de la yerba Guinea (Panicum maximum) y de yerba Buffel (Cenchrus ciliaris) se usaron en este estudio para evaluar la técnica del rumen artificial, o sea, la técnica de la digestión de celulosa in vitro (1). Estas muestras de forrajeras cuyo valor nutritivo es conocido (4), y además, ya determinado en pruebas convencionales de digestibilidad con ganado vacuno (3), fueron cosechadas de los 49 a los 55 días y de los 63 a los 69 días de haberse sembrado en la Subestación de Gurabo.

No se estableció relación alguna entre el consumo ad libitum (consumo relativo-C.R. o consumo voluntario-C.V.) y la digestión de la celulosa in vitro (D.C.I.V.) a las $12 \mathrm{y}$ a las 24 horas. La variabilidad dentro de las pruebas, debido a las diferencias en los períodos de retraso, podría ser responsable de esto.

La D.C.I.V. a las 36 horas puede usarse para estimar la digestibilidad forrajera en términos de materia seca digestible (M.S.D.) $(r=0.95)$, energía digestible (E.D.) $(r=0.94)$, y nutrimentos digestibles totales (N.D.T.) $(r=0.94)$. La D.C.I.V. a las 48 horas también puede usarse para predecir la digestibilidad en términos de materia seca digestible (M.S.D.) $(r=0.87)$ e índice de valor nutritivo (I.V.N.) $(r=0.85)$. Sin embargo, las correlaciones más altas se obtuvieron con valores in vitro a las 36 horas. Existió una tendencia de los coeficientes de correlación a aumentar hasta las 36 horas de fermentación, según aumentaba la D.C.I.V.

Se calcularon las siguientes ecuaciones de regresión para predecir M.S.D. in vitro $(Y)$, E.D. in vitro $(Y)$ y N.D.T. in vitro $(Y)$ de la D.C.I.V. a las 36 horas $(X): Y=12.84+1.23 X, Y=1.801 X-11.76$ é $Y=17.79+$ $0.906 X$, respectivamente.

La digestión máxima de la celulosa se obtuvo aparentemente a las 60 
horas en cuatro de las seis yerbas forrajeras estudiadas. Cuando se alimentaron dos animales con la misma clase de forraje, no se encontraron diferencias marcadas en los valores de la D.C.I.V. a las 60 y a las 72 horas.

\section{LITERATURE CITED}

1. Arroyo-Aguilú, J. A., Evans, J. L., and Taylor, M. W., The artificial-rumen technique for estimating the nutritive value of forages, J. Agr. Univ. P.R. 47 (3): 169-79, 1963.

2. Arroyo-Aguilú, J. A., and Rivera-Anaya, J. D., Plastic cannula for rumen fistula, J. Agr. Univ. P.R. 49(2): 269-70, 1965.

3. Arroyo-Aguilú, J. A., and Rivera-Brenes, L., Digestibility studies on Napier (Merker) grass (Pennisetum purpureum), Giant Pangola grass (Digitaria valida Stent.), and Signal grass (Brachiaria brizantha), J. Agr. Univ. P.R. $45(33)$ : 151-6, 1961.

4. Arroyo-Aguilú, J. A., Rivera-Brenes, L., Acosta-Matienzo, A., and Carrero, R., The nutritive evaluation of Buffel grass (Cenchrus ciliaris) and Guinea grass hybrid (Panicum maximum) as compared to Napier (Merker) grass (Pennisetum purpureum), J. Agr. Univ. P.R. (in press).

5. Baumgardt, B. R., Taylor, M. W., and Cason, J. L., Evaluation of forages in the laboratory, II, Simplified artificial rumen procedure for obtaining repeatable estimates of forage nutritive value, $J$. Dairy Sci. 45: 62-7, 1962.

6. Chalupa, W., and Lee, Jr., D. D., Estimation of forage nutritive value from in vitro cellulose digestion, J. Dairy Sci. 49: 188-92, 1966.

7. Crampton, E. W., and Maynard, L. A., The relation of cellulose and lignin content to the nutritive value of animal feeds, J. Nutr. 15: 383-95, 1938.

8. Donefer, E., Crampton, E. W., and Lloyd, L. E., Prediction of the nutritive value index of a forage from in vitro rumen fermentation data, J. Anim. Sci. 19: 545$52,1960$.

9. Donefer, E., Lloyd, L. E., and Crampton, E. W. Effect of several variables of the in vitro digestion of forage cellulose, J. Anim. Sci. 20: 959, 1961.

10. Hershberger, T. V., Long, T. A., Hartsook, E. W., and Swift, R. W., Use of the artificial rumen technique to estimate the nutritive value of forages, J. Anim. Sci. 18: 770-9, 1959.

11. Matrone, G., A. Study of Lignin and Cellulose Methods for the Chemical Evaluation of Feeds, M.S. Thesis, Cornell University, Ithaca, N.Y., 1944.

12. Naga, M. M. A., and El-Shazly, K., The use of in vitro fermentation technique to estimate the digestible energy content of some Egyptian forages, I. The in vitro digestion of cellulose as a criterion of energy content, J. Agr. Sci. 61: 73-9, 1963.

13. Quicke, G. V., Bentley, O. G., Scott, H. W., and Moxon, A. L., Cellulose digestion in vitro as a measure of the digestibility of forage cellulose in ruminants, $J$. Anim. Sci. 18: 275-87, 1959.

14. Reid, R. L., Clark, B., Welch, J. A., Jung, G. A., and Shelton, D. C., Relationship of forage digestibility and intake data to in vitro and in vivo fermentation indices, J. Anim. Sci. 19: 1312, 1960.

15. Steel, R. G. D., and Torrie, J. H., Principles and Procedures of Statistics, McGraw-Hill Book Co., Inc., New York, N.Y., 1960. 